NBER WORKING PAPER SERIES

\title{
EVALUATING EFFECTS OF TAX PREFERENCES ON HEALTH CARE SPENDING AND FEDERAL REVENUES
}

\author{
John F. Cogan \\ R. Glenn Hubbard \\ Daniel P. Kessler \\ Working Paper 12733 \\ http://www.nber.org/papers/w12733 \\ NATIONAL BUREAU OF ECONOMIC RESEARCH \\ 1050 Massachusetts Avenue \\ Cambridge, MA 02138 \\ December 2006
}

Cogan is the Leonard and Shirley Ely Senior Fellow at the Hoover Institution at Stanford University. Hubbard is Dean and Russell L. Carson Professor of Finance and Economics at the Graduate School of Business and Professor of Economics at Columbia University; and Research Associate of the National Bureau of Economic Research. Kessler is Professor of Business and Law at Stanford University, Senior Fellow at the Hoover Institution at Stanford University, and Research Associate of the National Bureau of Economic Research. This paper was prepared for the NBER Tax Policy and the Economy Conference, to be held in Washington, D.C., on September 14, 2006. We are grateful to Joe Antos, Doug Holtz-Eakin, Jim Poterba, and conference participants for helpful comments. The views expressed herein are those of the author(s) and do not necessarily reflect the views of the National Bureau of Economic Research.

(C) 2006 by John F. Cogan, R. Glenn Hubbard, and Daniel P. Kessler. All rights reserved. Short sections of text, not to exceed two paragraphs, may be quoted without explicit permission provided that full credit, including $\odot$ notice, is given to the source. 
Evaluating Effects of Tax Preferences on Health Care Spending and Federal Revenues

John F. Cogan, R. Glenn Hubbard, and Daniel P. Kessler

NBER Working Paper No. 12733

December 2006

JEL No. H2,H5,I1

\section{ABSTRACT}

In this paper, we calculate the consequences for health spending and federal revenues of an above-the-line deduction for out-of-pocket health spending. We show how the response of spending to this expansion in the tax preference can be specified as a function of a small number of behavioral parameters that have been estimated in the existing literature. We compare our estimates to those from other researchers. And, we use our analysis to derive some implications for tax policy toward HSAs.

John F. Cogan

Hoover Institution

Stanford University

Stanford, CA 94305

cogan@hoover.stanford.edu

R. Glenn Hubbard

Graduate School of Business

Columbia University, 609 Uris Hall

3022 Broadway

New York, NY 10027

and NBER

rgh1@columbia.edu
Daniel P. Kessler

Graduate School of Business

Stanford University

518 Memorial Way, Room L241

Stanford, CA 94305

and NBER

fkessler@stanford.edu 
As Mark Pauly's (1986) classic review shows, virtually all observers of health policy since Martin Feldstein's (1973) seminal article have agreed that the tax preference for employer-provided health insurance -- under which employer contributions to employee health insurance are deductible to the employer and non-taxable to the employee -- encourages overconsumption of health services in the United States. By making health spending in general, and insured health spending in particular, appear less costly than they are, the tax preference gives employees the incentive to take compensation as health insurance rather than cash, even if they would otherwise prefer not to.

Both the budget cost of the tax preference, and its potential implications for efficiency in markets for health services, are large. Table 1 provides three estimates of the federal revenue loss from the tax preference in 2004. John Shiels and Randall Haught (2004) estimate that the revenue loss to be $\$ 188.5$ billion. According to them, the loss from the exclusion from the personal income tax base of employer contributions to employee health insurance alone was $\$ 114.7$ billion. The Joint Committee on Taxation (2003) estimates this loss to be slightly less ( $\$ 101.0$ billion); the Department of the Treasury in the Office of Management and Budget (OMB, 2003) estimates it to be slightly more ( $\$ 123.9$ billion). Everyone agrees, however, that it dwarfs the revenue loss from all other health tax preferences (such as the deduction for health spending in excess of 7.5 percent of adjusted gross income), and indeed is the single largest tax preference in the federal budget. According to the Department of the Treasury in OMB (2003), the loss from the employer exclusion surpasses the loss from the deductibility of mortgage interest, state and local property taxes, and all capital gains tax preferences. Indeed, the 
only personal tax preferences that come close are the various exclusions for retirement savings contributions.

Table 2 presents trends in health spending by payor and form of spending for 1993-2003. The table documents the well-known growth in the magnitude of real spending over this period. Particularly noteworthy is the change in the form of health spending, from (largely taxable) out-of-pocket to tax-preferred insured spending. According to the table, real employer and employee payments for insured health spending rose about 50 percent over the period, while out-of-pocket spending rose less than half as much. If the tax preference contributed to this, and insured spending is subject to a greater degree of moral hazard, then the impact of the preference on efficiency could be substantial.

Taken together, these factors have led academic researchers to focus on the consequences of revoking the tax preference. Yet, policymakers over the past 30 years have taken an alternative approach; they have sought to level the tax playing field by expanding the tax preference rather than eliminating it. ${ }^{1}$ In 1978 , changes to section 125 of the Internal Revenue Code allowed health expenditures made through an employerprovided Flexible Spending Account (FSA) to be deductible to the employer but nontaxable to the employee. ${ }^{2}$ In 1996, the Health Insurance Portability and Accountability Act allowed employees of small businesses who were covered by certain high-deductible health plans (HDHPs) to make tax-free contributions to a Medical

\footnotetext{
${ }^{1}$ Such a pattern likely reflects politics as much as economics: the vast majority of voters benefit from the excludability of health insurance. When President Reagan expressed interest in eliminating or even limiting the exclusion, his proposal was soundly rejected in Congress. Indeed, the Clinton health reform plan explicitly rejected any such limitations (Cutler 1994).

${ }^{2}$ An FSA allows employees to allocate a portion of their compensation to nontaxable fringe benefits instead of taxable wages. Currently, once the amount of the FSA contribution has been designated, the employee is not allowed to change it or drop the plan during the year unless he or she experiences a change of family status. By law, the employee forfeits any unspent funds in the account at the end of the year.
} 
Savings Account (MSA). Funds from an MSA can be withdrawn, tax free, to pay for medical expenses in the present or the future; if used for other purposes after age 65, MSA distributions are taxed as ordinary income. Under Treasury regulations issued in 2002, sections 105 and 106 of the Internal Revenue Code allow health reimbursement accounts (HRAs) to reimburse employees for medical expenses with before-tax dollars, without the use-it-or-lose-it provision of section 125 cafeteria plans. ${ }^{3}$ In 2003, the Medicare Prescription Drug, Improvement, and Modernization Act allowed employers and individuals with any HDHP to make tax-free contributions to a health savings account (HSA). President Bush has proposed expanding the use of HSAs by liberalizing their contribution limits.

Conditional on the tax preference for insurance remaining in place, the consequences of these expansions for health spending, and economic efficiency, are theoretically indeterminate. Expanding the tax preference has two opposing effects. First, expansion lowers the overall price of health care relative to other goods and services, which increases distortionary spending. Second, expansion raises the price of purchasing health care through insurance relative to out-of-pocket. The second effect induces people to shift to health plans with higher deductibles and coinsurance rates, which, in turn, lowers distortionary spending.

Thus, assessing the effects of expanding the tax preference to out-of-pocket spending is important for evaluating existing and proposed tax policies toward health care. Yet, very little work has sought to estimate these effects and to understand their sensitivity to assumptions about the demand for health services and insurance. In this

\footnotetext{
${ }^{3}$ HRAs, however, are owned by the employer and contributions to them are subject to nondiscrimination rules; that is, they can not be at the employee's discretion. See U.S. Department of Labor (2003).
} 
paper, we present a simplified version of the approach in John Cogan, R. Glenn Hubbard, and Daniel Kessler (CHK, 2005) to calculating the effects of an above-the-line deduction for out-of-pocket health spending, which we term "full deductibility." In that paper, we show how the response of total health spending to an expansion in the tax preference can be specified as a function of a small number of behavioral parameters that have been estimated in the existing literature. This paper expands on that work in three ways. First, it calculates the effects of full deductibility on out-of-pocket spending, total spending, and the government budget under a range of parameter values. Second, it compares our estimates to those from other researchers. Third, it uses our analysis to derive some implications for tax policy toward HSAs.

\section{Assessing the effects of tax deductibility on health spending}

As reviews by Pauly (1986) and, more recently, Thomas Selden and John Moeller (2000) show, a substantial body of research has sought to assess the effects of revoking the tax preference for employer-provided health insurance. Considerably less work has focused on the effects of extending the preference to out-of-pocket spending. William Jack and Louise Sheiner (1997) simulate the effects on insurance policy choice, health spending, and efficiency of both revoking and extending the tax preference. Those authors show that extending deductibility might actually reduce health spending and improve efficiency, by leading to such a large increase in the effective coinsurance rate that the gain from the reduction in moral hazard swamps the loss from the reduction in the overall price of health care. A recent working paper by Jack, Arik Levinson, and Sjamsu Rahardja (2005) provides empirical support for this hypothesis. They show that, 
correcting for selection effects, FSAs are associated with effective coinsurance rates that are about 7 percentage points higher, relative to a sample average coinsurance rate of 17 percent. This finding suggests that making out-of-pocket health spending deductible, which an FSA effectively does, would significantly change the form of the average health insurance contract.

In CHK (2005), we derive the relationship between the impact on health spending of making out-of-pocket expenses tax deductible and two parameters from economic studies: the price elasticity of health spending, and the elasticity of the coinsurance rate with respect to the tax preference for insured spending. We specify health spending $E$ as a function of the after-tax price of health services relative to all other goods $p$ and the tax preference for out-of-pocket spending relative to insured spending $t_{\mathrm{o}} / t_{\mathrm{i}}, E\left(p, t_{o} / t_{i}\right)$. In a world without taxes, $p$ is the price of health services $p^{*}$. In a world with tax preferences, $p$ is $p^{*}$ multiplied by the weighted average of the tax preferences for out-of-pocket spending $t_{\mathrm{o}}$ and insured spending $t_{\mathrm{i}}, p=p^{*} \times\left[c t_{o}+(1-c) t_{i}\right]$, where $t_{\mathrm{o}}$ and $t_{\mathrm{i}}$ are weighted by the quantity shares of out-of-pocket and insured spending $c$ and $(1-c)$, respectively. The share $c$ can also be thought of as the coinsurance rate -- that is, the share of spending out-of-pocket in the absence of tax preferences.

So

$$
\frac{d E}{d t_{o}}=\frac{\partial E}{\partial p} \times \frac{\partial p}{\partial t_{o}}+\frac{\partial E}{\partial\left(t_{o} / t_{i}\right)} \times \frac{\partial\left(t_{o} / t_{i}\right)}{\partial t_{o}}=\frac{\partial E}{\partial p} \times \frac{\partial p}{\partial t_{o}}+\frac{\partial E}{\partial\left(t_{o} / t_{i}\right)} \times \frac{1}{t_{i}}
$$

and

$$
\frac{d E}{d t_{i}}=\frac{\partial E}{\partial p} \times \frac{\partial p}{\partial t_{i}}+\frac{\partial E}{\partial\left(t_{o} / t_{i}\right)} \times \frac{\partial\left(t_{o} / t_{i}\right)}{\partial t_{i}}=\frac{\partial E}{\partial p} \times \frac{\partial p}{\partial t_{i}}-\frac{\partial E}{\partial\left(t_{o} / t_{i}\right)} \times \frac{t_{o}}{t_{i}^{2}}
$$

Then the sum of these two equations, in elasticity terms, is: 
$\frac{d E / E}{d t_{o} / t_{o}}+\frac{d E / E}{d t_{i} / t_{i}}=\frac{\partial E / E}{\partial p / p} \times \frac{\partial p / p}{\partial t_{o} / t_{o}}+\frac{\partial E / E}{\partial\left(t_{o} / t_{i}\right)} \times \frac{t_{o}}{t_{i}}+\frac{\partial E / E}{\partial p / p} \times \frac{\partial p / p}{\partial t_{i} / t_{i}}-\frac{\partial E / E}{\partial\left(t_{o} / t_{i}\right)} \times \frac{t_{o}}{t_{i}}$

or

$\frac{d E / E}{d t_{o} / t_{o}}+\frac{d E / E}{d t_{i} / t_{i}}=\frac{\partial E / E}{\partial p / p} \times\left[\frac{\partial p / p}{\partial t_{o} / t_{o}}+\frac{\partial p / p}{\partial t_{i} / t_{i}}\right]=\frac{\partial E / E}{\partial p / p} \times\left[\frac{p^{*} \times\left[c t_{o}+(1-c) t_{i}\right]}{p}+\theta\left(t_{o}, t_{i}, p^{*}\right)\right]$

or

$$
e\left(t_{o}\right)+e\left(t_{i}\right)=e(p) \times\left[1+\theta\left(t_{o}, t_{i}, p^{*}\right)\right]
$$

where $e\left(t_{o}\right)$ is the elasticity of spending with respect to the tax preference for out-ofpocket spending; $e\left(t_{i}\right)$ is the elasticity of spending with respect to the preference for insured spending; and $e(p)$ is the price elasticity of spending.

In CHK (2005), we show that under reasonable assumptions and current market conditions and tax preferences, ${ }^{4} \theta($.$) is small, so$

$$
e\left(t_{o}\right)+e\left(t_{i}\right) \approx e(p)
$$

Finally, we translate the results from previous studies into these terms. For example, the equation above can be rewritten as

$$
e\left(t_{o}\right)+\left(e(c) \times e\left(c, t_{i}\right)\right) \approx e(p)
$$

where $e(c)$ is the elasticity of spending with respect to the coinsurance rate and $e\left(c, t_{i}\right)$ is the elasticity of the coinsurance rate with respect to the tax preference for insured spending. If demand curves are locally linear, then $e(p)=e(a p)$ for any positive constant $a$, so $e(p)=e(c)$, which implies:

$$
e\left(t_{o}\right) \approx e(p) \times\left(1-e\left(c, t_{i}\right)\right) .
$$

\footnotetext{
${ }^{4}$ For example, $t_{0}=1$ and $t_{i}=0.7$.
} 
Assessing the effects of extending deductibility thus requires estimates of $e(p)$ and $e\left(c, t_{i}\right)$. There is a range of estimates of $e(p)$. Based on the RAND Health Insurance Experiment, Willard Manning and colleagues (1987) estimate $e(p)=-0.2$ in arc elasticity terms. ${ }^{5}$ In more recent work, Matthew Eichner (1997, table 1) estimates $e(p)=-0.7$ (average for all employees 1990-92, also in arc elasticity terms). ${ }^{6}$ In addition, even the high end of this range may understate the impact of a market-wide change in incentives such as extending deductibility. All of the estimates of $e(p)$ are based on responses to individual-level changes in copayments, which may be smaller than the responses to more widespread changes in insurance contracts that fundamentally alter how doctors practice medicine. Amy Finkelstein (2005), for example, shows that the change in hospital spending associated with the introduction of Medicare was far greater than the elasticities from the RAND Experiment would have predicted.

Less disagreement surrounds the magnitude of $e\left(c, t_{i}\right)$. Several studies have assessed the effect of the tax preference on coinsurance rates. These can be used to compute $e\left(c, t_{i}\right)$. Early simulations by Martin Feldstein and Bernard Friedman (1977)

\footnotetext{
${ }^{5}$ Because the tax preference leads to large changes in effective prices for health services, point elasticities expressed in (current) after-tax terms will be very different from those expressed in (counterfactual) pre-tax terms. For example, the effect of a 1 percent increase in the effective coinsurance rate from its current (lower) base is much smaller than the effect of a 1 percent decrease in the effective coinsurance rate from its (higher) base in the absence of the tax preference. Some of the studies we review provide estimates in the former terms; some provide estimates in the latter. We follow the convention used in the RAND study and convert all elasticities into arc terms, expressed at the average between pre- and post-tax prices.

6 The published estimates in Eichner (1997, table 1) are based on models that assume that consumers make marginal health spending decisions throughout the year based on the coinsurance rate that they face at the end of the year. This assumption is important because many plans' coinsurance rates vary with a consumer's level of cumulative spending over a calendar year. For example, a plan may have a $\$ 500$ deductible (i.e., a coinsurance rate of $100 \%$ on the first $\$ 500$ of spending), a coinsurance rate of $25 \%$, and a $\$ 2,000$ out-of-pocket maximum (i.e., a coinsurance rate of $0 \%$ after $\$ 1,500$ in coinsurance payments or $\$ 6,500$ in total spending). If consumers have rational expectations, then this assumption is correct. Regardless of when in the year the choice to make a (marginal) health expenditure arises, the effective coinsurance rate for any marginal expenditure would be the rate in effect after all of the year's expenditures had occurred. In the text of the article, Eichner points out that estimates of e $(p)$ from models that do not assume rational expectations are generally lower. However, in our view, the rational expectations assumption is more justifiable than the alternatives, so we use the estimates from the table.
} 
suggest that revoking the tax preference for employer-provided insurance would lead to a doubling in the coinsurance rate (from approximately 25 to 50 percent). This finding is consistent with an unpublished estimate by Charles Phelps (1986). More recent work leads to virtually the same conclusions. At conservative levels of consumer risk aversion and $e(p)$, simulations by Jack and Sheiner (1997, table 2) find that the tax preference for insurance has led optimal coinsurance rates to shrink from 33-67 percent to 20-30 percent. Assuming an average marginal (payroll plus income) tax rate of 30 percent, $^{7}$ revocation leading to doubling of coinsurance rates from $c$ to $2 c$ implies an $e\left(c, t_{i}\right)$ in arc elasticity terms of 1.9 , because:

$$
\frac{\frac{2 c-c}{[2 c+c] / 2}}{\frac{1-(1-.3)}{[1+(1-.3)] / 2}}=1.9 \text {. }
$$

Table 3 presents calculations of the effects of revoking and extending the income and payroll tax preference for $e(p)=-0.2,-0.45$, and -0.7 at $e\left(c, t_{i}\right)=1.9$. The first two rows of Table 3 present the effects of revoking the income and income-and-payroll tax preference which is simply

$$
e(p) \times e\left(c, t_{i}\right) \times d t_{i} / t_{i}
$$

The third and fourth rows of Table 3 present the effects of extending the income and income-and-payroll tax preference which is simply

$$
e(p) \times\left(1-e\left(c, t_{i}\right)\right) \times d t_{o} / t_{o}
$$

\footnotetext{
${ }^{7}$ We discuss how we assess the magnitude of the average marginal tax rate in more detail below.
} 
Our estimates of the effects of tax policy on spending are within the range of those from other research. For example, according to Jonathan Gruber (2002, table 5), removing the income tax subsidy for health insurance would result in a 32.8 percent decline in health spending, expressed as a percentage point change from its initial value. Expressed as a percentage-point change at the average (in order to make his estimate comparable to those in table 1), this amounts to a 39.2 percent decline -- larger than the 31.8 percent decline in spending that we would predict even assuming an elasticity of spending with respect to the coinsurance rate of 0.7 . Gruber's estimate, when combined with the consensus estimate of $e\left(c, t_{i}\right)=1.9$, implies that extending the income tax preference to out-of-pocket spending would result in a decline in overall spending of 11.8 percent. ${ }^{8}$ According to Jack and Sheiner (1998, table 1), extending the income and payroll tax preference to out-of-pocket spending would lead to a decline in spending of 4.9 percent $(=0.3 / 6.15)$, slightly lower than the decline in spending that we would predict assuming an elasticity of spending of 0.2 .

\section{Assessing the budget implications of extending deductibility to out-of-pocket spending}

In addition to reducing inefficient health spending, full deductibility reduces federal tax revenues. Deductibility has two effects on revenues -- a loss from making previously taxable spending deductible, and a gain from the shift away from previously deductible health spending. We do not account for any possible spillover effects from privately-purchased health care to the Medicare or Medicaid programs.

\footnotetext{
${ }^{8}$ Gruber's estimate implies $e(p)=-0.87=0.392 /(1.9 * 0.19 * 2 /(0.7+0.89))$, which implies an effect of $0.118=-0.87 * 0.9 * 2 * 0.14 /(1+0.86)$.
} 
The revenue loss consists of two components -- the loss from allowing the abovethe-line deduction of out-of-pocket spending, and the loss from purchases on health insurance being deducted above-the-line that are currently not deducted or deductible. The revenue gain also consists of two components. Tax revenues rise because higher policy deductibles will translate into a shift in employees' compensation away from excludable health spending to taxable wages. ${ }^{9}$ The government picks up both payroll and income taxes on the portion of the wage increase directed to non-health spending (first component), and payroll taxes on the portion directed to out-of-pocket health spending (second component).

Table 4 presents our calculations of these losses and gains on an annual basis, in 2004 dollars. The first panel of the table shows the two components of the gross losses from full deductibility, based on the levels of out-of-pocket and insurance expenditures from CHK (2005). As the first panel shows, the gross losses are a mechanical consequence of the policy; they do not depend on behavior. We calculate that full deductibility would have a gross revenue cost of $\$ 26.8(=\$ 16.4+\$ 10.4)$ billion per year.

The second panel shows the two components of the gross gains, based on the levels of spending on health care overall and employer-provided health insurance from CHK (2005). First, full deductibility leads to a decline in total spending from current levels, in percentage terms, of $\eta^{*}$ because:

$$
\begin{aligned}
& \eta=\frac{\eta^{*}}{\left[1+\left(1+\eta^{*}\right)\right] / 2} \text { or } \\
& \eta^{*}=\frac{2 \eta}{2-\eta},
\end{aligned}
$$

\footnotetext{
${ }^{9}$ As Jonathan Gruber (2000) points out, empirical evidence supports the hypothesis that the costs of health insurance premiums are fully shifted out of wages.
} 
where $\eta$ is measured as a percentage decline at the average. Second, it leads to a decline in spending on employer-provided health insurance over and above the decline in total spending -- that is, a relative increase in out-of-pocket spending. To calculate this shift, we make the (conservative) assumption that spending for individuals with employerprovided health insurance responds to full deductibility the same as does all private health spending. Under this assumption, full deductibility leads to a decline in spending on employer-provided health insurance, in percentage terms, of

$$
\left(\frac{1-c^{\prime}}{1-c}\right) \times\left(1+\eta^{*}\right)
$$

where $c^{\prime}$ is the coinsurance rate that obtains under full deductibility and $\tau$ is the average marginal tax rate, with

$$
c^{\prime}=c \times\left[1+\frac{2(\eta / e(p))}{2-(\eta / e(p))}\right] / 1-\tau
$$

$2(\eta / e(p)) /[2-(\eta / e(p))]$ is the implied rise in the after-tax coinsurance rate necessary to induce the spending decline from table 3 ; dividing by $1-\tau$ converts this to the rise in the coinsurance rate that must obtain. The increase in out-of-pocket spending subject to the payroll tax is thus the difference between this decline and the decline in total spending from above, in dollar terms.

The bottom panel of the table shows the intermediate calculations on which the revenue gains from the policy are based. The first row of the bottom panel reports that the coinsurance rate under full deductibility would be 33.3 percent, regardless of the elasticity of demand for health services, up from a pre-deductibility average of 25 percent. (That the coinsurance rate does not vary with the elasticity of demand is, of course, a product of our model's assumption of a constant $e\left(c, t_{i}\right)$.) The last row reports 
the increase in out-of-pocket spending under varying assumptions about the elasticity of demand. It shows that that making out-of-pocket spending deductible above-the-line would result in a significant increase in out-of-pocket spending, from $\$ 149$ billion in 2004 dollars (=\$117 billion in currently non-deductible out-of-pocket spending plus \$32 billion in deductible spending, see CHK (2005, Appendix E)) to $\$ 190$ billion (=\$149 billion $+\$ 41$ billion, see column 2$)$, or 27.5 percent $(=(\$ 190$ billion $-\$ 149$ billion $) / \$ 149$ billion).

The calculations presented in table 4 make the important point that much of the gross revenue losses from full deductibility will be made up by revenue gains from the reduction in the inefficiency due to the highly-distortionary existing tax preference. Indeed, even assuming an elasticity of demand for health services of $-0.2, \$ 12.2$ billion of the $\$ 26.8$ billion (or 46 percent) of the losses will be undone; if the elasticity of demand is -0.45 , fully $\$ 18.3$ billion of the $\$ 26.8$ billion (or 68 percent) of losses are undone.

\section{Implications for policy toward HSAs}

Like full deductibility, allowing HSA contributions to be tax-deductible gives a tax preference to out-of-pocket spending. Under current law, a holder of an HDHP (i.e., a health plan with a deductible of at least $\$ 1,050 / \$ 2,100$ in 2006 (individual/family)) can contribute to an HSA the amount of the deductible, but not more than $\$ 2,700$ (individual) or $\$ 5,450$ (family). ${ }^{10}$ The contribution is deductible from federal income taxes and from income taxes in 44 states. $^{11}$ If the contribution is made by a person's employer, it is also excludable from the Social Security tax base. The contribution accumulates interest tax-

\footnotetext{
${ }^{10}$ This summary is taken from the detailed explanation of the tax treatment of HSAs in Internal Revenue Service (2004).

${ }^{11}$ See National Conference of State Legislatures (2006).
} 
free and is non-taxable on distribution, if spent on health services; it is taxable as ordinary income if distributed for any other purpose after age 65.

HSAs differ from full deductibility in three key ways. First, an individual can only have an HSA if they are enrolled in an HDHP. Second, an individual can deduct HSA contributions from his or her taxable income up to the amount of their HDHP's deductible, whether or not they incur any health expenses, but can not deduct more, even if they have coinsurance payments in excess of the deductible. Third, an HSA allows an individual to save tax-free for future health expenses or retirement, whereas full deductibility only allows deduction of current health expenses. ${ }^{12}$

For consumers who use HSAs only as a vehicle to deduct current health expenses, the most important difference between HSAs and full deductibility is the minimum deductible requirement of HDHPs. If, for these individuals, all of the expenditurereducing incentive effects of full deductibility were channeled through insurance policy deductibles (rather than coinsurance rates), then deductibles would have to rise from a typical value of $\$ 221$ (2004 dollars) ${ }^{13}$ to approximately $\$ 290,{ }^{14}$ far less than the 2006 mandated HDHP minimum of $\$ 1,050$. Because HSAs are indistinguishable from full deductibility for these consumers, this implies that they would prefer a lower deductible than the mandated minimum.

\footnotetext{
${ }^{12}$ Of course, adoption of full deductibility does not preclude HSAs. Indeed, full deductibility enhances the incentive to finance current health spending out of pocket, while HSAs (when used as a savings vehicle) enhance the incentive to accumulate assets to finance future health expenses out of pocket.

${ }^{13}$ See Jon Gabel and Tom Rice (2003).

${ }^{14}$ We reach this conclusion by using parameters from the RAND Health Insurance experiment, the approach suggested by Charles Phelps (2003), and the increase in health spending reported by CMS (2006). In 1984 dollars, the current deductible of $\$ 221$ would be equivalent to \$44. According to CMS (2006), spending per private health insurance enrollee rose from $\$ 675$ in 1984 to $\$ 3,379$ in 2004, a factor of five. According to Phelps (2003, table 5.6), to achieve the spending reduction of $2.7 \%$ from full deductibility predicted by the RAND Experiment, deductibles would have to have risen to $\$ 58$ in 1984 , or $\$ 290(=58 * 5)$ in 2004 .
} 
Because most taxpayers do not exhaust their existing retirement savings incentives (CBO 2003), and therefore are likely to treat HSAs primarily as a vehicle to deduct current expenses, HSAs as currently formulated will likely be taken up by fewer people than would full deductibility. However, among HSA enrollees, HSAs bring health spending much closer to the efficient level (the level that would be preferred in the absence of any tax preference) than full deductibility. If all of the expenditure-reducing incentive effects of revoking the income and payroll tax preferences were channeled through insurance policy deductibles, then deductibles would rise to approximately \$1,680 in 2004 dollars. ${ }^{15}$ These back-of-the-envelope comparisons between full deductibility and HSAs are consistent with empirical studies of HSAs (see, for example, Melinda Buntin et al. (2005) and Roger Feldman et al. (2005)) and MSAs (see, for example, Larry Ozanne (1996) and Emmett Keeler et al. (1996)).

The most efficient way to expand HSAs would be to allow deductibility of all outof-pocket payments for people with insurance (not just those toward the policy deductible), but limit the budget consequences of HSAs by capping deductible contributions at a fixed dollar amount (such as $\$ 1,000 / \$ 2,000$ for an individual/family, indexed to inflation) in excess of current health expenses. Two considerations support this shift.

First, recall that the back-of-the-envelope calculations above suggest that lowering the minimum deductible requirement is an important policy for increasing the takeup rate. For most consumers, the minimum deductible requirement is simply too high, given the magnitude of the existing tax preference for employer-provided

\footnotetext{
${ }^{15}$ To achieve the spending reduction of $13.4 \%$ from revoking the income and payroll tax preferences predicted by the RAND Experiment, deductibles would have to have risen to $\$ 336$ in 1984, or $\$ 1,680$ $(=336 * 5)$ in 2004.
} 
insurance. Allowing people to choose their policy deductible will solve this problem. Just as the takeup of managed care had beneficial spillovers to fee-for-service insurance (for example, Laurence Baker 1997), the takeup of HSAs and insurance plans with more cost sharing will as well.

Second, evidence from the RAND Experiment suggests that most of the expenditure-reducing effects of policy deductibles occur at low levels of deductibles (for example, Emmett Keeler et al. 1988). Extending deductibility to out-of-pocket expenses above the policy deductible will provide an important incentive for individuals to increase coinsurance rates as well. The results from the RAND experiment suggest that a mix of higher deductibles and coinsurance rates would achieve greater efficiency in health spending than mandating that all of the savings be channeled through the deductible.

\section{Conclusion}

The U.S. health care system, the envy of the world in innovation, faces criticisms from policymakers about the cost of care. From an economic perspective, an alternative approach is to ask whether private consumers of health care - and taxpayers who fund public programs - are obtaining the highest "value" for the resources devoted to health care. Healthy, competitive markets generally offer the greatest opportunity to maximize value.

As academic researchers have long observed, limiting or revoking altogether the tax preference for health insurance would improve the performance of markets for health services on this dimension. Current policy generally allows individuals to receive 
employer-provided health insurance expenditures tax-free, but requires direct out-ofpocket medical spending to be financed from after-tax income. This tax preference has given consumers the incentive to purchase health care through low-deductible, lowcopayment insurance instead of out of pocket. However, likely because the vast majority of voters benefit from this preference, policymakers over the past 30 years have instead sought to level the tax playing field by expanding the tax preference rather than eliminating it.

In this paper, we show that extending deductibility to out-of-pocket spending, while a second-best policy change, is nonetheless likely to lead to significant improvements in efficiency under a range of assumptions about demand for health care and health insurance. Although we are not the first to recognize this fact, we quantify the actual health spending and revenue effects of such a policy using a transparent accounting model and a small number of behavioral parameters from existing studies.

Providing additional evidence on the sensitivity of health insurance contracts to tax changes is a subject for future research. Also, while not emphasized here, expanding deductibility may also significantly reduce rates of uninsurance by lowering the cost of health insurance. Finally, we view as an important topic for future work more analysis of the relationship between tax deductibility and Health Savings Accounts. 
Table 1: Cost to the Federal Budget of Existing Tax Preferences for Health Spending 2004 (in billions of dollars)

\begin{tabular}{lcc}
\multicolumn{3}{c}{ Study } \\
Shiels \\
and \\
Haught & JCT & US Treasury in \\
$(2003)$ & $(2003)$ & OMB (2003)
\end{tabular}

Total

Exclusion of Employer Contribution to HI premiums from... social security payroll tax base Medicare payroll tax base personal income tax base Deduction for out-of-pocket expenses in excess of $7.5 \%$ of adjusted gross income
$\$ 188.5$

$\$ 52.2$

$\$ 14.2$

$\$ 114.7 \quad \$ 101.0 \quad \$ 123.9$

$\$ 7.4 \quad \$ 5.9$

$\$ 6.3$

Notes: Three studies' estimation methods differ slightly; see Shiels and Haught (2003) for discussion. 
Table 2: Health Spending, By Payor and Form of Spending 1993-2003 (in billions of 2003 dollars)

Type of Payor and Form of Spending

TOTAL

Private

Private Business

Employer Contribution to $\mathrm{HI}$ premiums

Employer payments of Medicare payroll taxes

Workers' Compensation and other

Household

Employee Contribution to $\mathrm{HI}$ premiums

Employee payments of Medicare payroll Individual payments of Medicare SMI

Out-of-pocket spending

Other Private

\section{Public}

Federal Government

Employer contributions to $\mathrm{HI}$ premiums

Medicaid

Medicare (net of payroll tax receipts) and

State and Local Government

Employer contributions to $\mathrm{HI}$ premiums

Medicaid

Other

$$
\begin{array}{llll} 
& \text { Year } & & \% \text { change } \\
1993 & 1998 & 2003 \quad 1993-2003
\end{array}
$$

$\$ 1,087.5 \quad \$ 1,257.2 \quad \$ 1,614.2 \quad 48.4 \%$

$\$ 694.4 \quad \$ 806.8 \quad \$ 992.2 \quad 42.9 \%$

$\$ 280.9 \quad \$ 325.1 \quad \$ 423.0 \quad 50.6 \%$

$\$ 205.1 \quad \$ 237.2 \quad \$ 320.6 \quad 56.3 \%$

$\$ 45.5 \quad \$ 60.8 \quad \$ 64.3 \quad 41.4 \%$

$\$ 30.4 \quad \$ 27.1 \quad \$ 38.1 \quad 25.5 \%$

$\$ 367.5 \quad \$ 423.5 \quad \$ 512.6 \quad 39.5 \%$

$\$ 110.4 \quad \$ 129.5 \quad \$ 174.1 \quad 57.8 \%$

$\$ 55.5 \quad \$ 78.2 \quad \$ 86.0 \quad 55.0 \%$

$\$ 15.1 \quad \$ 17.5 \quad \$ 22.0 \quad 45.6 \%$

$\$ 186.6 \quad \$ 198.4 \quad \$ 230.5 \quad 23.6 \%$

$\$ 46.0 \quad \$ 58.2 \quad \$ 56.6 \quad 23.1 \%$

$\$ 393.1 \quad \$ 450.5 \quad \$ 622.0 \quad 58.2 \%$

$\$ 223.0 \quad \$ 243.0 \quad \$ 344.0 \quad 54.3 \%$

$\$ 14.6 \quad \$ 12.9 \quad \$ 19.7 \quad 34.9 \%$

$\$ 99.2 \quad \$ 115.0 \quad \$ 160.9 \quad 62.2 \%$

$\$ 106.2 \quad \$ 112.3 \quad \$ 160.2 \quad 50.9 \%$

$\$ 170.1 \quad \$ 207.5 \quad \$ 278.1 \quad 63.5 \%$

$\$ 48.5 \quad \$ 55.1 \quad \$ 86.2 \quad 77.7 \%$

$\$ 58.2 \quad \$ 83.1 \quad \$ 111.8 \quad 92.2 \%$

$\$ 57.2 \quad \$ 61.9 \quad \$ 71.5 \quad 25.1 \%$

Source: Health United States (2005), table 127, deflated with the CPI. 


\section{Table 3: Effect on Health Spending \\ of Changing the Tax Preference}

Effect of revoking:

income tax preference

Elasticity of spending with respect to after-tax price of health care

$\begin{array}{lll}-0.2 & -0.45 & -0.7\end{array}$

income plus payroll tax preference

$-9.1 \% \quad-20.4 \% \quad-31.8 \%$

$-13.4 \% \quad-30.2 \% \quad-46.9 \%$

Effect of extending to out-of-pocket: income tax preference

$\begin{array}{lll}-2.7 \% & -6.1 \% & -9.5 \%\end{array}$

income plus payroll tax preference

$-5.6 \% \quad-12.6 \% \quad-19.7 \%$

Note: Assumes a health-spending-weighted average marginal income tax rate of .19, out-ofpocket-spending-weighted average marginal income tax rate of .14, and an average payroll tax rate of .13. Average marginal tax rates were calculated using MEPS, and include both households with and without income tax liabilities. See CHK (2005) for details. 
Table 4: Effect on Tax Revenues

of Full Deductibility

Revenue Losses

Elasticity of spending with respect to after-tax price of health care

$\begin{array}{lll}-0.2 & -0.45 & -0.7\end{array}$

Loss from deduction of taxable out-

of-pocket spending

$\begin{array}{lll}-\$ 16.4 & -\$ 16.4 & -\$ 16.4\end{array}$

Loss from deduction of taxed or

taxable insurance payments

$\begin{array}{lll}-\$ 10.4 & -\$ 10.4 & -\$ 10.4\end{array}$

Revenue Gains

Shift away from health spending

Pickup of payroll taxes

Pickup of income taxes

$\$ 2.4$

$\$ 5.3$

$\$ 8.1$

$\begin{array}{lll}\$ 3.5 & \$ 7.7 & \$ 11.8\end{array}$

Shift away from employer-insured

spending toward out-of-pocket

Pickup of payroll taxes

$\$ 6.3$

$\$ 5.3$

$\$ 4.3$

$\underline{\text { Total }}$

$-\$ 14.5$

$-\$ 8.4$

$-\$ 2.5$

Intermediate calculations underlying

estimates of revenue gains

New coinsurance rate

Reduction in health spending

Reduction in employer-insured

spending

Increase in out-of-pocket spending

(difference)

$\begin{array}{lll}33.3 \% & 33.3 \% & 33.3 \% \\ -\$ 18.4 & -\$ 40.7 & -\$ 62.3 \\ -\$ 67.2 & -\$ 81.6 & -\$ 95.6 \\ & & \\ \$ 48.8 & \$ 40.9 & \$ 33.3\end{array}$

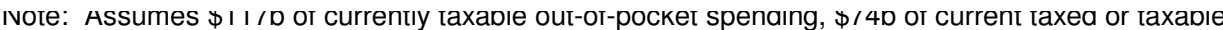
insurance payments, $\$ 500 \mathrm{~b}$ of current spending on employer health insurance, $\$ 688 \mathrm{~b}$ of total private health spending, an average coinsurance rate of $25 \%$, a health-spending-weighted average marginal income tax rate of .19, out-of-pocket-spending-weighted average marginal income tax rate of .14, and an average payroll tax rate of .13. See note to table 1 and CHK (2005) for details on calculation of average marginal tax rates. 


\section{References}

Baker, Laurence, The effect of HMOs on fee-for-service health care expenditures: evidence from Medicare, Journal of Health Economics 16: 4: 453-81, 1997.

Centers for Medicare and Medicaid services, Office of the Actuary, National Health Statistics, http://www.cms.hhs.gov/NationalHealthExpendData/downloads/tables.pdf, 2006.

Cogan, John F., R. Glenn Hubbard, and Daniel P. Kessler, Healthy, Wealthy, and Wise, Hoover Insitution/AEI Press, 2005.

Congressional Budget Office, Utilization of Tax Incentives for Retirement Saving, August 2003.

Cutler, David, A Guide to Health Care Reform, Journal of Economic Perspectives 8:1330, 1994.

Buntin, Melinda et al., Consumer Directed Health Plans: Implications for Health Care Quality and Cost, http://www.chcf.org/documents/insurance/ConsumerDirHealthPlansQualityCost.pdf, 2005.

Eichner, Matthew, The Demand for Medical Care: What People Pay Does Matter, American Economic Review 88:117-121, 1998.

Feldman, Roger et al., Health Savings Accounts: Early Estimates of National Take-up, Health Affairs 24: 1582-91, 2005.

Feldstein, Martin, The Welfare Loss from Excess Health Insurance, Journal of Political Economy 81: 251-80, 1973.

Feldstein, Martin and Bernard Friedman, Tax Subsidies, the Rational Demand for Insurance, and the Health Care Crisis, Journal of Public Economics 7: 155-178, 1977.

Finkelstein, Amy, The Aggregate Effects of Health Insurance: Evidence from the Introduction of Medicare, NBER Working Paper 11619, 2005.

Gabel, Jon and Tom Rice, Insurance Markets: Understanding Consumer Directed Health Care in California, California Health Care Foundation, www.chcf.org/documents/insurance/ConsumerDirectedHealthCare.pdf, 2003.

Gruber, Jonathan, Health Insurance and the Labor Market, in A.J. Culyer and J.P. Newhouse, eds., Handbook of Health Economics, 2000, North-Holland. 
Gruber, Jonathan, Taxes and Health Insurance, in James Poterba, ed., Tax Policy and the Economy, Volume 16, 2002, MIT Press.

Health United States, US Centers for Disease Control, 2005.

Internal Revenue Service, Notice 2004-2, Health Savings Accounts, http://www.irs.gov/irb/2004-02_IRB/ar09.html, 2004.

Jack, William, Arik Levinson, and Sjamsu Rahardja, Employee Cost-sharing and the Welfare Effects of Flexible Spending Accounts, working paper, 2005.

Jack, William and Louise Sheiner, Welfare-Improving Health Expenditure Subsidies, American Economic Review 87: 206-221, 1997.

Joint Committee on Taxation, Estimates of federal Tax Expenditures for Fiscal Years 2004-08, Pub. No. JCS-8-03, 2003.

Keeler, Emmett et al., Can Medical Savings Accounts for the Nonelderly Reduce Health Care Costs? JAMA 275(21): 1666-71, June 1996.

Keeler, Emmett et al., The Demand for Episodes of Medical Treatment in the Health Insurance Experiment, RAND R3454-HHS, March 1988.

Manning, Willard G. et al., Health Insurance and the Demand for Medical Care:

Evidence from a Randomized Experiment, American Economic Review 251-277, 1987.

National Conference of State Legislatures, 2004-2006 State Legislation on Health Savings Accounts and Consumer-Directed Health Plans, http://www.ncsl.org/programs/health/hsa.htm\#2005, 2006.

Office of Management and Budget, Budget of the US Government: Analytical Perspectives, Fiscal Year 2004, Chapter 6: Tax Expenditures, 2003.

Ozanne, Larry, How Will Medical Savings Accounts Affect Medical Spending? Inquiry 33: 225-36, 1996.

Pauly, Mark V., Taxation, Health Insurance, and Market Failure in the Medical Economy, Journal of Economic Literature 24: 629-75, 1986.

Phelps, Charles E., Large-Scale Tax Reform: The Example of Employer Paid Health Insurance Premiums, working paper, 1986.

Phelps, Charles E. Health Economics, 3d. Edition, Addison-Wesley, 2003.

Selden, Thomas F. and John Moeller, Estimates of the Tax Subsidy for EmploymentRelated Health Insurance, National Tax Journal 53: 877-888, 2000. 
Shiels, John and Randall Haught, The Cost of Tax-Exempt Health Benefits in 2004, Health Affairs Web Exclusive W4106-112, February 2004.

U.S. Department of Labor, Bureau of Labor Statistics, Health Spending Accounts, www.bls.gov/opub/cwc/cm20031022ar01p1.htm, 2003. 